\title{
A New Species of Cophixalus (Anura: Microhylidae) from Misima Island, Papua New Guinea ${ }^{1}$
}

\author{
Stephen 7. Richards ${ }^{2,3}$ and Paul M. Oliver ${ }^{2}$
}

\begin{abstract}
Cophixalus misimae Richards \& Oliver, n. sp., is described from lowaltitude rain forest on Misima Island, Louisiade Archipelago, Papua New Guinea. It is a small (males 15.5-16.1 mm, females 19.3-19.6 mm) terrestrial species with a visible tympanum, a snout that is distinctly truncate in dorsal view, unwebbed toes, a dark brown lateral stripe, and a call consisting of a train of high-pitched pulses. It is the third species of Cophixalus known from the Louisiade Archipelago and is currently known only from Misima Island.
\end{abstract}

The microhylid genus Cophixalus is one of the most ubiquitous components of the eastern New Guinea frog fauna (Zweifel and Tyler 1982, Kraus and Allison 2000). Despite their abundance in many areas (e.g., Simon 1983) the genus remains poorly studied, with no comprehensive taxonomic treatment in existence. Recent surveys have documented a number of new Copbixalus species (e.g., Richards 2002), and five new taxa were described between 2000 and 2003 (Kraus and Allison 2000, Jones 2002, Günther 2003). These studies increased the number of described Cophixalus in New Guinea to 21 (Frost 2004). An additional 14 species of $\mathrm{CO}_{0}$ phixalus are known from northeastern Australia (Zweifel 1985, Hoskin 2004).

The Louisiade Archipelago is a series of continental islands extending in a southeasterly direction from the southeastern tip of mainland New Guinea. Two species of $\mathrm{C}_{0-}$ phixalus (C. aimbensis and C. tagulensis) are known from this region, and both appear to

${ }^{1}$ The South Australian Museum board, the Mark Mitchell Foundation, and the Winifred Violet Scott Estate provided funding assistance to S.J.R. During preparation of the manuscript S.J.R. was supported by a grant from Conservation International. Manuscript accepted 2 June 2006.

2 Vertebrates Department, South Australian Museum, North Terrace, Adelaide, South Australia 5000, Australia.

${ }^{3}$ Correspondence (phone: +6188207 7473; fax +61 88207 7222; e-mail: richards.steve@saugov.sa.gov.au).

Pacific Science (2007), vol. 61, no. 2:279-287

(C) 2007 by University of Hawai'i Press

All rights reserved be endemic to Sudest (Tagula) Island. One other species (C. verrucosus) with a broad distribution on mainland Papua New Guinea is known from the nearby D'Entrecasteaux Islands. In the course of fieldwork on Misima Island S.J.R. collected a series of small terrestrial Cophixalus that could not be assigned to any of these three species or to any other recognized Cophixalus. These frogs are herein described as a new taxon.

\section{MATERIALS AND METHODS}

Upon collection, specimens were fixed in $10 \%$ formalin and subsequently stored in $70 \%$ ethanol. Measurements (to $0.1 \mathrm{~mm}$ ) were made with dial calipers and a microscope fitted with an ocular micrometer and follow Zweifel (1985) and Zweifel and Parker (1989). They were of snout-vent length (SV), tibia length (TL), arm length (AL), head width at the angle of the jaws (HW), head length as a straight-line distance from angle of jaws to tip of snout (HL), eye diameter (EYE), internarial distance (IN), eye-naris distance (EN), horizontal diameter of tympanic membrane (EAR), width of third finger disk at right angle to digital axis (3FD) and width of penultimate phalanx of third finger (3FP), width of first finger disk (1FD) and first phalanx (1FP), and of fourth toe disk (4TD) and fourth toe phalanx (4TP), as for third finger. One specimen of the new species was cleared and stained using the method of Dingerkus and Uhler (1977).

Advertisement calls from a single male were recorded with a tape recorder (Sony 
TCM 5000EV) and microphone (Sennheiser ME66). Eight calls were analyzed using a sound analysis program (AVISOFT SAS-Lab Pro). Temperature adjacent to the calling male was measured with a quick-reading thermometer (Miller \& Weber). Specimens are deposited in the South Australian Museum (sama), Adelaide, and the Natural Sciences Resource Centre of the University of Papua New Guinea (UPNG). Other specimens examined were from the following institutions: AMNH, American Museum of Natural History, New York; вм, Natural History Museum, London; врвм, Bernice P. Bishop Museum, Honolulu; mcz, Museum of Comparative Zoology, Harvard; and MSNG, Museo Civico di Storia Naturale Genova, Genoa.

Locality coordinates for the new species use the Global Positioning System datum WGS84.

\section{TAXONOMIC TREATMENT}

Cophixalus misimae Richards \& Oliver, n. sp. Figures 1, 2A, 3

holotype. sama R60286, adult male, 8 November 2002, from "Fill 3 Forest," 200$250 \mathrm{~m}$ above sea level (asl), Misima Mine Site (152 $\left.{ }^{\circ} 47.761^{\prime} \mathrm{E}, 10^{\circ} 39.540^{\prime} \mathrm{S}\right)$, Misima Island, Louisiade Archipelago, Milne Bay Province, Papua New Guinea, collected by S. Richards.

PARATYPES. UPNG 9969, adult male, 10 November 2002, and UPNG 9970, adult female, 1 November 2002, same locality as holotype; sama R60287, adult male, 5 November 2002, and sAMA R60288, adult female, 4 November 2002, both from "North Dump Rainforest," 250-300 m asl (152 $47.876^{\prime} \mathrm{E}$, $10^{\circ} 39.848^{\prime}$ S); sAMa R60289 (cleared and stained), adult male, 16 October 2003, Boma Village $\left(152^{\circ} 47.064^{\prime} \mathrm{E}, 10^{\circ} 39.090^{\prime} \mathrm{S}\right)$, all specimens collected by S. Richards.

Diagnosis. The new species is a Cophixalus based on the following combination of characters: (1) jaws eleutherognathine and clavicles and all other prezonal elements of the pectoral girdle absent; (2) snout not elongate (as in Choerophryne); (3) translucent pad

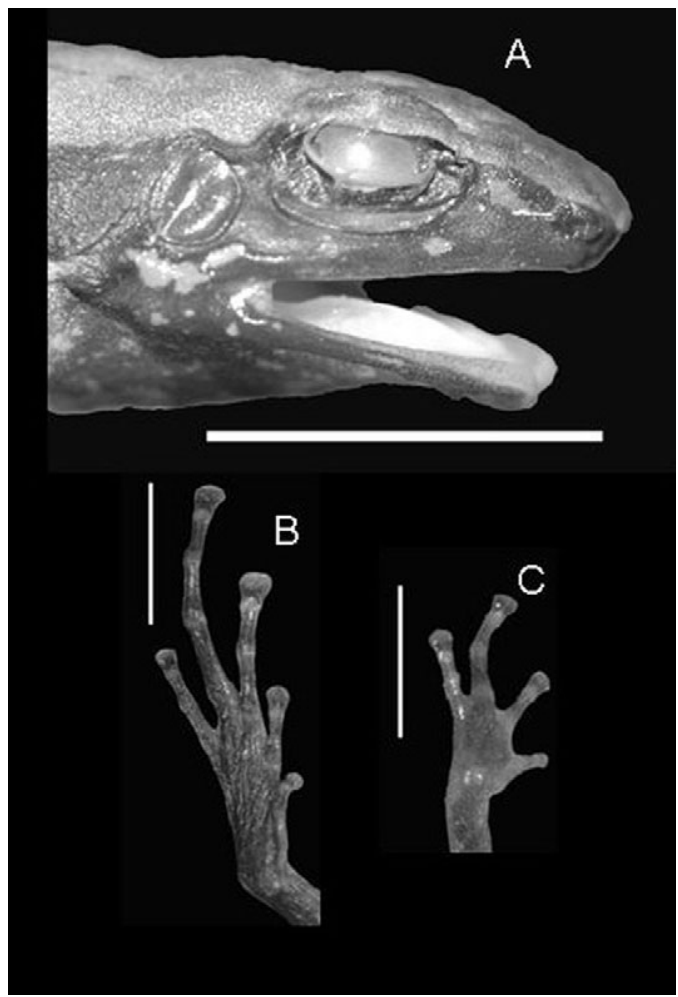

Figure 1. Cophixalus misimae Richards \& Oliver, n. sp. $A$, Lateral view of head of holotype (sama R60286), scale bar $=5 \mathrm{~mm} ; B$, plantar surface, and $C$, palmar surface of paratype (sAMA R60287), scale bar $=2.5 \mathrm{~mm}$.

on tip of snout absent (present in most Copiula), and supplementary slip of $\mathrm{m}$. intermandibularis narrow, directed anteromedially, inserting upon the fascia of the $\mathrm{m}$. submentalis (versus supplementary slip of the $\mathrm{m}$. intermandibularis more or less transverse, with a broad insertion onto the median raphe of the m. intermandibularis in Copiula [Burton 1984, 1990]); (4) fifth toe shorter than the third (longer in Albericus), m. depressor mandibulae arising primarily from a broad origin on dorsal fascia, and otic ramus of squamosal bone short (versus most of origin of $\mathrm{m}$. depressor mandibulae arising from otic ramus, with a very much smaller origin from dorsal fascia, and otic ramus of squamosal elongated in Albericus); and (5) toes with terminal disks bearing circummarginal grooves, and relatively long hind limbs (TL/SV 0.52 
0.56) (versus disks absent and tibiae short [TL/SV < 0.37] in Aphantophryne [Zweifel and Parker 1989]).

Cophixalus misimae can be distinguished from all congeners by the following combination of characters: (1) small size (maximum $19.6 \mathrm{~mm}$ ); (2) tympanum distinct; (3) dark brown lateral band extending from tip of snout to approximately two-thirds distance between fore and hind limbs; (4) snout prominent, protruding in lateral view, tip distinctly truncate in dorsal view; (5) loreal region steep, nearly vertical; (6) distinct dark brown spot above inguinal region; (7) toes with moderately enlarged, rounded disks and without webbing; (8) fingers 2-4 with moderately enlarged disks, first finger not markedly reduced, with a small but distinct terminal disk; (9) advertisement call a long train of pulses lasting up to $5 \mathrm{sec}$.

Description of holotype. Measurements are presented in Table 1. Adult male with vocal slits. Body slender, head moderately narrow $(\mathrm{HW} / \mathrm{SV}=0.36)$. Snout prominent, distinctly protruding in lateral view; narrowing markedly anterior of eyes with distinctly truncate tip in dorsal view. Canthus rostralis rounded but prominent, straight with slight indentation posterior of nostrils. Loreal region slightly concave, near vertical; labial region vertical. Internarial distance greater than distance from external naris to eyes $(\mathrm{EN} / \mathrm{IN}=0.81)$. Eyes moderately large $(\mathrm{EYE} / \mathrm{SV}=0.14)$. Tympanum half diameter of eye $(\mathrm{EAR} / \mathrm{EYE}=0.55)$, conspicuous with well-defined tympanic annulus; tongue ovoid. Supratympanic, posttympanic, and dorsolateral folds absent. In life dorsum and upper portion of hind limbs smooth with scattered low tubercles. In preservative skin smooth, without tubercles. Fingers unwebbed, relative lengths $3>4>2>1$, finger 1 one-third length of finger 2 when adpressed. No subarticular or metacarpal tubercles. Disks on fingers 2-4 slightly shriveled, but in life rounded and at least twice as wide as penultimate phalanx; disk of finger 1 small, barely exceeding width of phalanx but with distinct circummarginal groove. Toes unwebbed, relative lengths $4>3>5>2>1$, without subarticular or metatarsal tubercles. Disks shriveled, in life rounded and at least twice as wide as penultimate phalanx. All disks with circummarginal grooves.

In preservative, dorsum pale grayish brown with numerous tiny, dark brown maculations, eyelid distinctly darker. Ventral ground color yellowish off-white, with numerous scattered, tiny brown spots of various density. Areas with highest density of spotting appear brown. Throat dark brown with scattered small, light spots. A pair of distinct dark spots dorsally above inguinal region, few smaller brown flecks between these large spots and urostyle. Dark brown U-shaped marking around ventral edge of vent, sharply demarcated against dorsal coloration but grading into ventral coloration and extending along tibiae. Broad, dark brown, lateral band extends from tip of snout approximately twothirds of the distance between fore and hind limbs, sharply demarcated against dorsal coloration but grading into ventral coloration through interdigitating areas of dark brown and yellowish off-white. Arms and legs with same grayish brown dorsal and yellowish offwhite ventral coloration as body. Lateral surface of arms with a number of longitudinally oriented dark brown spots, brown spotting becoming more dense along forearm; hands, fingers, and lower limbs extensively spotted with dark brown. Legs dorsally uniformly yellowish brown, laterally with a number of longitudinally oriented dark spots, ventrally heavily spotted with brown, density of spotting increasing distally.

Variation. Measurements of the type series are presented in Table 1. Females are larger than males; this size dimorphism is typical of the genus (Zweifel 1962, 1979), and in all other respects the females resemble the males. Coloration is fairly uniform. One specimen (sama R60288) has a very pale, thin middorsal stripe. Most specimens exhibit a second pair of distinct (but smaller) dark brown spots in the inguinal region posterior to the large pair (absent in the holotype). Brown markings on the throat of some specimens extend onto the abdomen. The extent of brown ventral markings on the hind legs varies from absent on the tibiae to extending distally about halfway along the tibiae. 


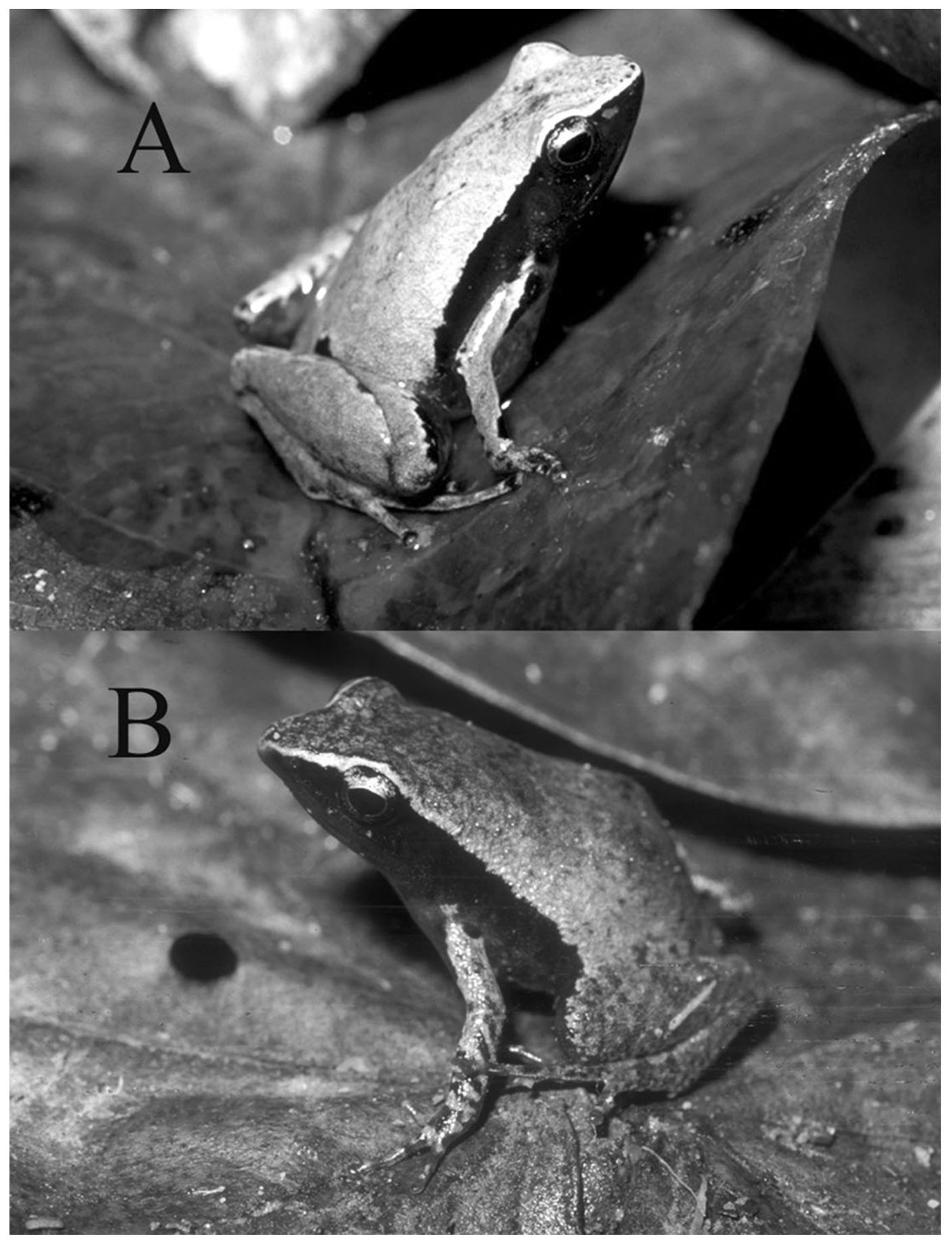

Figure 2. Photographs of $A$, Cophixalus misimae in life from Misima Island, Milne Bay Province, Papua New Guinea; and $B$, Batrachylodes trossulus from the Solomon Islands, showing morphological convergence between the two species. 
TABLE 1

Measurements (mm) and Ratios for the Type Series of Cophixalus misimae

\begin{tabular}{|c|c|c|c|c|c|c|}
\hline $\begin{array}{l}\text { Frog No. } \\
\text { Sex }\end{array}$ & $\begin{array}{c}\text { UP2676 } \\
M\end{array}$ & $\begin{array}{c}\text { R56871 } \\
M\end{array}$ & $\begin{array}{c}\text { R60287 } \\
M\end{array}$ & $\begin{array}{c}\text { R60286 } \\
M\end{array}$ & $\begin{array}{c}\mathrm{R} 60288 \\
\mathrm{~F}\end{array}$ & $\begin{array}{c}\text { UP2842 } \\
\text { F }\end{array}$ \\
\hline SV & 16.1 & 15.5 & 15.9 & 16.1 & 19.3 & 19.6 \\
\hline $\mathrm{EN}$ & 1.5 & 1.3 & 1.2 & 1.3 & 1.4 & 1.6 \\
\hline HW & 5.2 & 5.1 & 5.1 & 5.8 & 6.4 & 6.0 \\
\hline HW/SV & 0.32 & 0.33 & 0.32 & 0.36 & 0.33 & 0.31 \\
\hline EYE & 2.2 & 2.2 & 2.1 & 2.2 & 2.7 & 2.6 \\
\hline TL & 9.0 & 8.6 & 8.7 & 8.9 & 10 & 10.4 \\
\hline TL/SV & 0.56 & 0.55 & 0.55 & 0.55 & 0.52 & 0.53 \\
\hline IN & 1.9 & 1.7 & 1.7 & 1.6 & 2.0 & 2.0 \\
\hline EN/IN & 0.79 & 0.76 & 0.71 & 0.81 & 0.7 & 0.8 \\
\hline $\mathrm{HL}$ & 5.5 & 5.4 & 5.4 & 5.7 & 5.9 & 6.5 \\
\hline EAR & 1.1 & 1.0 & 1.2 & 1.2 & 1.3 & 1.4 \\
\hline TD & 0.7 & 0.7 & 0.6 & 0.7 & 0.7 & 0.7 \\
\hline ТP & 0.3 & 0.3 & 0.3 & 0.3 & 0.3 & 0.4 \\
\hline FD & 0.5 & 0.4 & 0.5 & 0.5 & 0.5 & 0.5 \\
\hline $\mathrm{FP}$ & 0.3 & 0.2 & 0.2 & 0.3 & 0.3 & 0.3 \\
\hline
\end{tabular}

ADVERTISEMENT CALl. The advertisement call is a long train of pulses lasting up to 5 sec (mean $=4.4, \quad \mathrm{SD}=0.345$, range $=3.93-4.98, n=8)$ containing 75-94 pulses $($ mean $=84, \mathrm{SD}=6.37)$ with a pulse rate of $18.78-19.11 / \mathrm{sec} \quad($ mean $=18.98$, $\mathrm{SD}=0.118)$. Dominant frequency is $5,080-$ $5,369 \mathrm{~Hz}$ (mean $=5,252 \mathrm{~Hz}, \mathrm{SD}=110.958$ $\mathrm{Hz}$ ). Individual pulses from the two bestquality calls were $0.0101-0.0241 \mathrm{sec}(n=158$ pulses). Pulses at the start of each call train were shortest, and pulses gradually became longer toward the end of each pulse train. A single call is illustrated in Figure 3. Air temperature at time of recording was $26^{\circ} \mathrm{C}$.

COMPARISONS WITH OTHER SPECIES. ItS small size $(<20 \mathrm{~mm})$ and dark unbroken lat- eral band extending from the head onto the body easily distinguish Copbixalus misimae from all other Cophixalus except $C$. shellyi, $C$. ateles, and $C$. pipilans. These three species are distinguished from $C$. misimae in having dark lateral bands or markings restricted predominantly to the head and not extending beyond the axilla (Zweifel 1956) (versus extending laterally well past midway between arms and legs). Cophixalus shellyi can be further distinguished by the possession of comparatively wider fingers and toes. Cophixalus ateles and the recently described $C$. bewaniensis further differ from the new species in having a very short first finger without a disk (Zweifel 1956, Kraus and Allison 2000). From C. pulchellus the new species can be distinguished

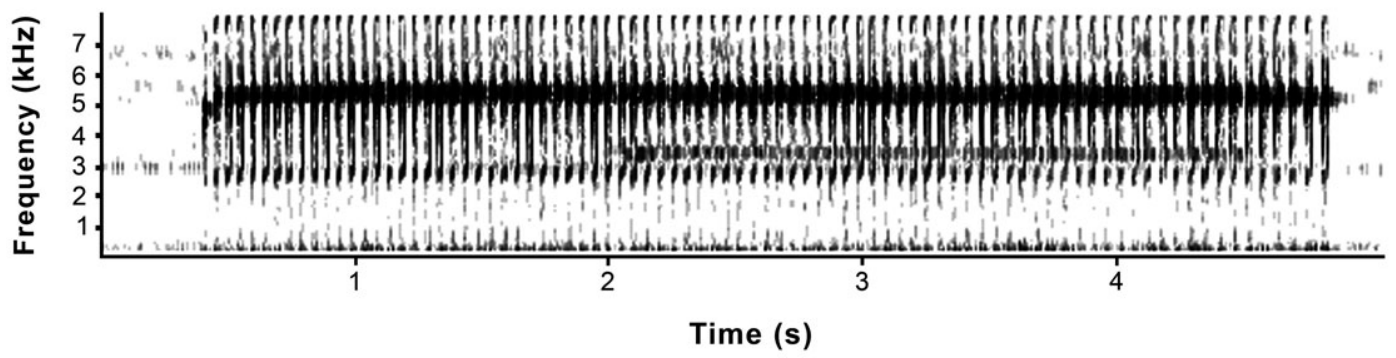

Figure 3. Audiospectrogram of a single call of Cophixalus misimae holotype (sama R60286). 
by its dark lateral band and its rather uniform dorsal coloration (versus large irregular blotches on a silvery background in $C$. pulchellus [Kraus and Allison 2000]). The straight, well-defined canthus rostralis of C. misimae superficially resembles that of $C$. cheesmanae, but $C$. cheesmanae is a scansorial species with broad terminal disks that can be readily differentiated by its larger size (males to more than $30 \mathrm{~mm}$ [Zweifel 1979] versus $16.1 \mathrm{~mm}$ ), absence of a prominent dark lateral band, and acute as opposed to truncate snout tip. From the two most geographically proximate described species, C. aimbensis and C. tagulensis, both from Sudest (Tagula) Island, C. misimae differs in its possession of a broad, dark lateral band (absent in C. aimbensis and C. tagulensis). It further differs from $C$. aimbensis in its much smaller size $(<20 \mathrm{~mm}$ versus 27.8 $34.6 \mathrm{~mm} \mathrm{SV}$ ) and from C. tagulensis in its distinct tympanum and unwebbed toes (webbed in tagulensis) (Zweifel 1963, Jones 2002).

There is also a notable level of morphological convergence between Cophixalus misimae and Batrachylodes trossulus. Although the ranid genus Batrachylodes can be readily distinguished internally from Cophixalus by the possession of robust prezonal elements of the pectoral girdle, externally $B$. trossulus is a similar size $(15.6-20.1 \mathrm{~mm})$, has a similar overall shape, and has the same color pattern as $C$. misimae, including a dark brown lateral stripe, gray dorsum, and very dark brown ventral "bib" (Figure 2). It is also a terrestrial species that occupies similar, lowland environments in the Solomon Islands to the east of the Louisiade Archipelago (S.J.R., pers. obs.). This species can be distinguished externally from $C$. misimae by its acuminate snout and having the first finger more than half the length of the second finger (versus less than half length of second finger). The morphological similarity between $C$. misimae and $B a-$ trachylodes trossulus is a striking example of the strong tendency of even very distantly related frogs in similar ecological niches to show extensive morphological convergence (Bossuyt and Milankovitch 2000).

natural history. Cophixalus misimae is most common in rain forest, where frogs live in litter on the forest floor (Figure 4). Five of

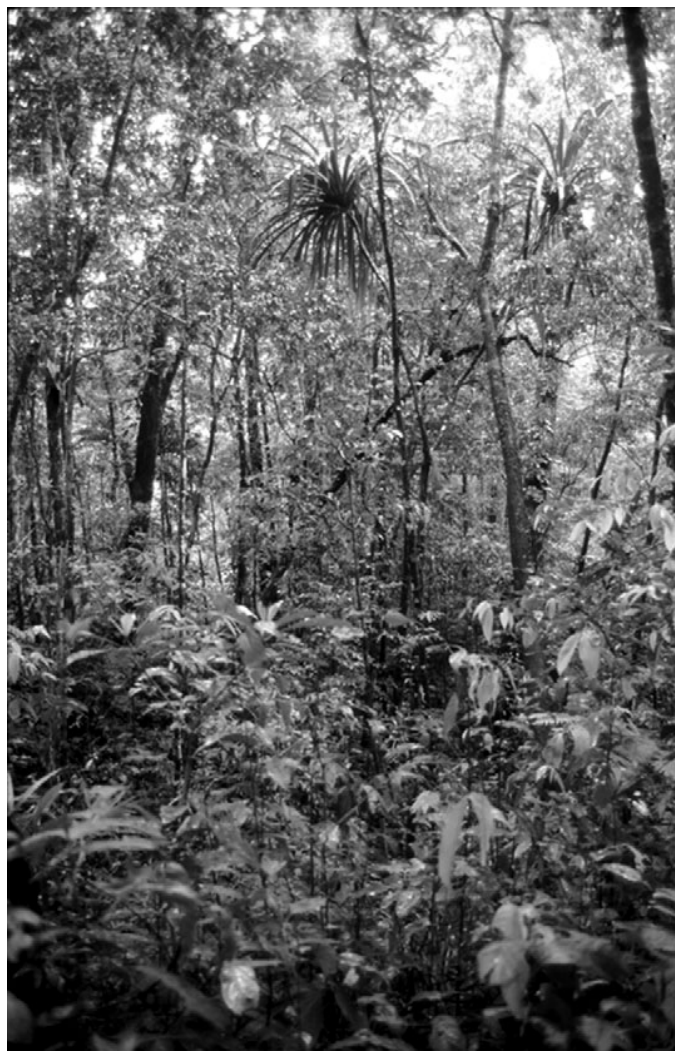

FIgURE 4. Rain-forest habitat of Cophixalus misimae on Misima Island.

the six known specimens were obtained in pitfall and funnel traps; only one of these was outside rain forest. It was collected from moist, dense rain-forest regrowth of an old garden adjacent to rain forest. One specimen (sAma R60286) was calling from leaf litter in thick rain forest undergrowth after rain. Several other individuals were heard calling sporadically from similar habitats. Calling occurred only during or immediately following rain. Cophixalus misimae occurred microsympatrically with four other microhylid frogs: Copiula oxyrbina, Callulops robustus, Oreophryne undescribed sp., and Hylophorbus undescribed sp.

distribution. Currently known only from Misima Island (Figure 5).

етумоlogy. The name refers to the type 


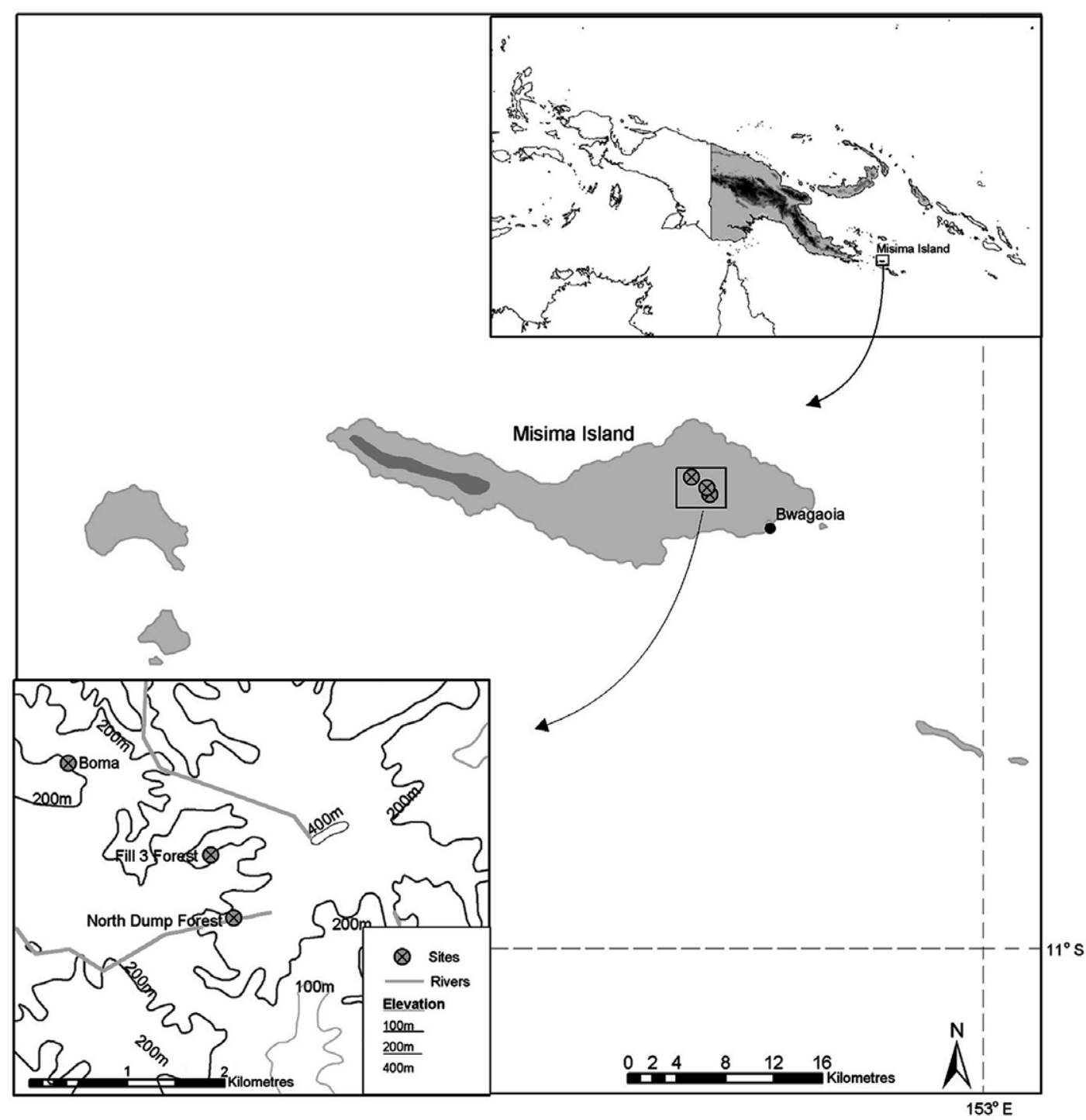

Figure 5. Map of Misima Island showing localities from which Cophixalus misimae has been collected. Darker shading indicates areas over $500 \mathrm{~m}$ asl.

locality, Misima Island, the only known locality for this species.

specimens examined. Cophixalus aimbensis. Papua New Guinea: Milne Bay Province: Aimba River, Tagula Island, $11^{\circ} 29^{\prime}$ S, $153^{\circ} 29^{\prime}$ E (UPNG 8469 [holotype], UPNG 8460-8468, 8470).

Cophixalus ateles. Papua New Guinea:
Central Highlands Province: Moroka (вм 1947.2.12.7, вм 1947.2.12.6 [paralectotypes], MSNG 29116, MSNG 50182).

Cophixalus bewaniensis. Papua New Guinea: West Sepik Province: Mt. Menawa, 3.312 ${ }^{\circ}$ S, $141.700^{\circ} \mathrm{E}$ (врвм 13741 [holotype]).

Cophixalus cheesmanae. Papua New Guinea: Kokoda (вм 1947.2.11.97 [holotype]); Lake- 
kamu, Gulf Province, $7^{\circ} 44.05^{\prime} \mathrm{S}, 146^{\circ} 29.45^{\prime}$ E (sama R60800); Southern Lowlands: Pio River (sama R9161); Morobe Province: Garaina (sAma R10648).

Cophixalus cryptotympanum. Papua New Guinea: Milne Bay Province: Mt. Dayman (вм 1956.1.1.19, АмNH 56843, АмNH 56740, AMNH 56827, AMNH 56743, AMNH 56828, AMNH 56747 [paratypes]).

Cophixalus parkeri. Papua New Guinea: Western Highlands Province: Mt. Wilhelm (MCz 25940 [holotype]).

Cophixalus pipilans. Papua New Guinea: Morobe Province: Lae area (sama R18082).

Cophixalus pulchellus. Papua New Guinea: East Sepik Province: Hunstein Mountains, $4.523^{\circ} \mathrm{E}, 142.675^{\circ} \mathrm{S}$ (врвм 13744 [holotype]).

Cophixalus shellyi. Papua New Guinea: North-East New Guinea: Kondiu, across the Wahgi River, near Kup (AмNH 58551 [holotype]).

Cophixalus verrucosus. Papua New Guinea: Central Highlands Province, Moroka (MSNG 29934 [lectotype], MSNG 50177 [paralectotype]); Mt. Victoria ( вм 1947.2.12.10); Milne Bay Province: Alotau (sama R11160-11161); Central Province: Sogeri (sama R15254).

Batrachylodes trossulus. Solomon Islands: Isabel Province, Barora Faa, 07 $32.065^{\prime} \mathrm{S}$, $158^{\circ} 21.005^{\prime} \mathrm{E}$ (sama R56981); Isabel Province: Kolopakisa, $07^{\circ} 36.008^{\prime} \mathrm{S}, 158^{\circ} 39.092^{\prime}$ E (sama R56870, R56871, cleared and stained); Choiseul Province: Rob Roy, $07^{\circ}$ $23.550^{\prime} \mathrm{S}, 157^{\circ} 35.830^{\prime}$ E (sAma R56939, 56940); Choiseul Province: Posarae, $07^{\circ}$ $20.648^{\prime}$ S, $157^{\circ} 12.829^{\prime}$ E (sama R56987).

\section{DISCUSSION}

The discovery of Cophixalus misimae increases to three the number of Cophixalus species known from the Louisiade Archipelago. However the distinctive combination of morphological features exhibited by $C$. misimae, including a distinctly truncate snout, small but distinct disk on first finger, and dark lateral band, do not suggest affinities with either of the other Louisiade species $(C$. aimbensis and $C$. tagulensis [see comparisons in preceding section]). The congener that superficially most closely resembles $C$. misimae in color- ation and morphology is $C$. shellyi, a montane species with a reduced first finger lacking a terminal disk (Zweifel 1956). However, that species is scansorial (S.J.R., pers. obs.), in contrast to the terrestrial habits of $C$. misimae. Indeed, very few Australopapuan Cophixalus are terrestrial, and relatively few occupy lowland environments (Zweifel 1985, Richards et al. 1994, Kraus and Allison 2000). The discovery of such an ecologically and morphologically distinctive Cophixalus underlines how much remains to be learned about the diverse microhylid frog fauna of New Guinea.

\section{ACKNOWLEDGMENTS}

Fieldwork on Misima Island and manuscript preparation were supported by Misima Mining Ltd. (MML). S.J.R. is particularly grateful to Walter Benko, Jamie White, and Tanya Zeriga of the MML Environment Department for their invitation and support, and to the enthusiastic field staff of the Environment Department, who so ably and cheerfully assisted with this project. Export permits were supplied by the Papua New Guinea (PNG) Department of Environment and Conservation, and we are particularly grateful to Barbara Roy for organizing these. As usual, Rose Singadan and Paulus Kei provided invaluable assistance in Port Moresby. Jim Robins of the PNG National Research Institute is gratefully acknowledged for his ongoing support of S.J.R.'s research program in PNG. Vera Weisbecker performed the clearing and staining, and Tom Burton kindly assisted with the generic diagnoses.

\section{Literature Cited}

Bossuyt, F., and M. C. Milankovitch. 2000. Convergent adaptive radiations in Madagascan and Asian ranids reveal covariation between larval and adult states. Proc. Natl. Acad. Sci. U.S.A. 97:6585-6590.

Burton, T. C. 1984. A new character to distinguish the Australian microhylid genera Cophixalus and Sphenophryne. J. Herpetol. 18:205-207.

- 1990. The New Guinea genus Co- 
piula Méhelÿ (Anura: Microhylidae): A new diagnostic character and a new species. Trans. R. Soc. S. Aust. 114:87-93.

Dingerkus, G., and L. D. Uhler. 1977. Enzyme clearing of alcian blue stained whole small vertebrates for demonstration of cartilage. Stain Technol. 52:229-232.

Frost, D. 2004. Amphibian species of the world 3.0; an online reference (http:// research.amnh.org.herpetology/amphibia/ index).

Günther, R. 2003. First record of the microhylid frog genus Cophixalus from western Papua, Indonesia, with descriptions of two new species. Herpetozoa 16:3-21.

Hoskin, C. J. 2004. Australian microhylid frogs (Cophixalus and Austrochaperina): Phylogeny, taxonomy, calls, distribution and breeding biology. Aust. J. Zool. 52:237-269.

Jones, H. 2002. A new species of Cophixalus (Anura: Microhylidae) from Tagula Island, New Guinea. Sci. New Guinea 27:96-100.

Kraus, F., and A. Allison. 2000. Two new species of Cophixalus from New Guinea. J. Herpetol. 34:535-541.

Richards, S. J. 2002. Rokrok: An illustrated guide to the frogs of the Kikori River Basin. World Wildlife Fund-Papua New Guinea, Port Moresby.

Richards, S. J., A. Dennis, M. Trennery, and G. Werren. 1994. A new species of Cophixalus (Anura: Microhylidae) from northern Queensland. Mem. Queensl. Mus. 37:307-310.

Simon, M. P. 1983. The ecology of parental care in the terrestrial breeding frog $\mathrm{Co}^{-}$ phixalus parkeri from New Guinea. Behav. Ecol. Sociobiol. 14:61-68.

Zweifel, R. G. 1956. Notes on microhylid frogs, genus Cophixalus, from New Guinea. Am. Mus. Novit. 1785:1-8.

1962. Results of the Archbold Expeditions. No. 83. Frogs of the microhylid genus Cophixalus from the mountains of New Guinea. Am. Mus. Novit. 2087:1-26.

. 1963. Results of the Archbold Expeditions. No. 84. New microhylid frogs (Baragenys and Cophixalus) from the Louisiade Archipelago, New Guinea. Am. Mus. Novit. 2141:1-10.

- 1979. A new cryptic species of microhylid frog (genus Cophixalus) from $\mathrm{Pa}$ pua New Guinea, with notes on related forms. Am. Mus. Novit. 2678:1-14.

. 1985. Australian frogs of the family Microhylidae. Bull. Am. Mus. Nat. Hist. 182:265-388.

Zweifel, R. G., and F. Parker. 1989. New species of microhylid frogs from the Owen Stanley Mountains of Papua New Guinea and resurrection of the genus Aphantophryne. Am. Mus. Novit. 2954:1-20.

Zweifel, R. G., and M. J. Tyler. 1982. Amphibia of New Guinea. Pages 759-801 in J. L. Gressitt, ed. Biogeography and ecology of New Guinea. Monogr. Biol. 42. 
